\title{
Oxcarbazepine: validation and application of an analytical method
}

\author{
Paula Cristina Rezende Enéas, Renata Barbosa de Oliveira, Gerson Antônio Pianetti” \\ Department of Pharmaceutical Products, Faculty of Pharmacy, Federal University of Minas Gerais
}

\begin{abstract}
Oxcarbazepine (OXC) is an important anticonvulsant and mood stabilizing drug. A pharmacopoeial monograph for OXC is not yet available and therefore the development and validation of a new analytical method for quantification of this drug is essential. In the present study, a UV spectrophotometric method for the determination of OXC was developed. The various parameters, such as linearity, precision, accuracy and specificity, were studied according to International Conference on Harmonization Guidelines. Batches of $150 \mathrm{mg}$ OXC capsules were prepared and analyzed using the validated UV method. The formulations were also evaluated for parameters including drug-excipient compatibility, flowability, uniformity of weight, disintegration time, assay, uniformity of content and the amount of drug dissolved during the first hour.
\end{abstract}

Uniterms: Oxcarbazepine/quantitative analysis. Anticonvulsants/quantitative analysis. UV spectrophotometric/method validation. Capsules/dissolution.

Oxcarbazepina (OXC) é um fármaco anticonvulsivante e estabilizante do humor. O desenvolvimento e validação de método analítico para quantificação da OXC são de fundamental importância devido à ausência de monografias farmacopéicas oficiais para esse fármaco. Nesse trabalho, um método espectrofotométrico UV para determinação da OXC foi desenvolvido. O método proposto foi validado seguindo os parâmetros de linearidade, precisão, exatidão e especificidade de acordo com as normas da Conferência Internacional de Harmonização. Cápsulas de OXC $150 \mathrm{mg}$ foram preparadas e analisadas utilizando-se o método analítico validado. As formulações foram avaliadas com relação à compatibilidade fármaco-excipientes, fluidez, determinação de peso, tempo de desintegração, doseamento, uniformidade de conteúdo e quantidade do fármaco dissolvido após 60 minutos.

Unitermos: Oxcarbazepina/análise quantitativa. Anticonvulsivante/análise quantitativa. Espectrofotometria UV/validação do método. Cápsulas manipuladas/dissolução.

\section{INTRODUCTION}

Oxcarbazepine (OXC) is a keto analog of carbamazepine (CBZ) and is an important anticonvulsant and mood stabilizing drug. The exact mechanism of action of OXC is unknown, although it is believed to involve blockade of voltage-gated sodium channels (Kalis, Huff, 2001). It is quickly absorbed after oral administration and undergoes rapid and almost complete reductive metabolism to form the pharmacologically active 10-monohydroxy derivative (MHD) (Shorvon, 2000) (Figure 1).

Since OXC and its pharmaceutical formulations

\footnotetext{
*Correspondence: G. A. Pianetti. Departamento de Produtos Farmacêuticos, Faculdade de Farmácia - UFMG. Av. Antônio Carlos 6627 - Campus Pampulha - 31270-901 - Belo Horizonte - MG, Brazil. E-mail: pianetti@farmacia.ufmg.br
}<smiles>NC(=O)N1c2ccccc2C=Cc2ccccc21</smiles><smiles>CC(=O)ON1c2ccccc2CC(=O)c2ccccc21</smiles><smiles>NC(=O)N1c2ccccc2CC(O)c2ccccc21</smiles>

FIGURE 1 - Chemical structure of carbamazepine, oxcarbazepine and 10-monohydroxy derivative.

have not yet been listed in any of the Pharmacopoeias, an analytical method needs to be developed for the quality control of the product.

Several high-performance liquid chromatographic (HPLC) methods have been reported in the literature for 
the determination of OXC (Pathare et al., 2007; Qi et al., 2003). To the best of our knowledge, one spectrophotometric method has been reported for the analysis of this drug in the literature, based on the reduction of ferric ions in their salt form to ferrous ions by the drug (Ramaa et al., 2006). The HPLC method is widely employed in quality control assessment of drugs because of its sensitivity, repeatability and specificity. On the other hand, the use of spectroscopic techniques is a promising simple, faster, direct and relatively lower cost alternative for the determination of active drug content in pharmaceutical formulations which provides sufficient reliability. Hence, we developed a simple UV spectrophotometric method to determine OXC in pharmaceutical dosage forms. The method fulfilled the requirements of analytical quality necessary to be applied to the assay and content uniformity tests indicated by Brazilian Pharmacopoeia (1988) for finished pharmaceutical products when these are present as single active principles, and hence can be successfully applied for routine quality control of tablets or capsules.

\section{MATERIALS AND METHODS}

\section{Material}

Oxcarbazepine was generously donated by the Cristália pharmaceutical company (Brazil). Pregelatinized starch and microcrystalline cellulose were a generous gift from Colorcon (Brazil). Corn starch and sodium lauryl sulfate were purchased from Pharmacopéia - Attivos Magisttrais (São Paulo, Brazil). Magnesium stearate and lactose monohydrate were obtained from Ipiranga Química (São Paulo, Brazil). Talc was provided by Proquímios Comércio e Indústria Ltda (Rio de Janeiro, Brazil) and aerosil and mannitol from Henrifarma Produtos Químicos e Farmacêuticos Ltda (São Paulo, Brazil). High purity water was prepared by using a Milli-Q water purification system from Millipore. All other materials and solvents were of analytical reagent grade.

\section{Validation of UV spectrophotometric method}

The UV spectrophotometric method was performed at $305 \mathrm{~nm}$. Linearity: the calibration curve was obtained with nine concentrations of the standard solution $(10-90 \mu \mathrm{g} / \mathrm{mL})$. The solutions were prepared in triplicate. The linearity was evaluated by least-squares linear regression analysis and correlation coefficients were calculated $\left(\right.$ Excel $\left.^{\circledR}\right)$. Precision: the precision of the assay method was determined by repeatability (intra-day) and intermediate precision (inter-day). The intra-day preci- sion was evaluated by analyzing six samples at $100 \%$ $(50 \mu \mathrm{g} / \mathrm{mL})$ of the test concentration $(n=6)$. Similarly, the intermediate precision was evaluated on two consecutive days $(n=12)$. The concentration of OXC was determined and the value of relative standard deviation (\%R.S.D) of the assay method was calculated. Accuracy: accuracy was determined by spiking known amounts of the analyte into the placebo formulation (F1, F2 and F3) across the specified range of the analytical procedure to obtain 40,50 and $60 \mu \mathrm{g} / \mathrm{ml}(80,100$ and $120 \%)$. At each level, solutions were prepared in triplicate and the accuracy was evaluated in terms of percent recovery. Percent Recovery was calculated using the formula [\%Recovery $=100 \mathrm{x}$ Mean Experimental Concentration/ Theoretical Concentration]. Selectivity: the method selectivity was assessed by comparing UV spectrum obtained from the $\mathrm{OXC}$ with those obtained from placebo formulations (excipients solution in methanol without OXC). Robustness: three sample solutions were prepared each containing $50 \mu \mathrm{g} / \mathrm{mL}$, and analyzed in two different UV-visible spectrophotometers (Hewlett Packard 8453 and Shimadzu $160 \mathrm{~A}$ ) immediately after the preparation of the solutions. The data obtained was submitted to statistical analysis (Student's t test) at a significance level of 0.05. Detection and quantification limits: detection and quantification limits were determined based on the standard deviation of the response $(\sigma)$ and the slope $(\mathrm{S})$ of the calibration curve of the analyte. The detection limit may be expressed as $3.3(\sigma / \mathrm{S})$ and the quantification limit may be expressed as $10(\sigma / \mathrm{S})(\mathrm{ICH}, 1996)$.

\section{Development of capsule formulations}

\section{Differential scanning calorimetry (DSC)}

Compatibilities of several commonly used pharmaceutical excipients with $\mathrm{OXC}$ were evaluated using the Differential Scanning Calorimetry (DSC) technique. DSC thermograms of the drug alone, each excipient alone, and drug-excipient physical mixtures $(1: 1 \mathrm{w} / \mathrm{w})$ were derived from a DSC (TA-2910, TA-instruments). The instrument was calibrated with an indium standard. The compounds were ground for 5 min using a pestle and mortar. The powders obtained were slightly compacted in the aluminium pan by a steel plunger to achieve a uniform powder bed in contact with the pan bottom. The samples (2-4 mg) were heated $\left(25-250{ }^{\circ} \mathrm{C}\right)$ at a constant scanning speed $\left(10^{\circ} \mathrm{C} / \mathrm{min}\right)$, using nitrogen as the purging gas.

\section{Capsule formulations}

The formulations used in this study are shown in Table I. 
TABLE I - Formulations of $150 \mathrm{mg}$ OXC Capsules

\begin{tabular}{lcccl}
\hline Ingredient & $\begin{array}{c}\text { Formulation 1 } \\
(\%)\end{array}$ & $\begin{array}{c}\text { Formulation 2 } \\
(\%)\end{array}$ & $\begin{array}{c}\text { Formulation 3 } \\
(\%)\end{array}$ & Class \\
\hline Oxcarbazepine & 40.5 & 43 & 34.9 & Active \\
Microcel MC-101, microcrystalline cellulose & 34 & - & - & Diluent, disintegrant \\
Corn starch & 19 & - & - & Diluent, disintegrant \\
Lactose monohydrate, USP & - & - & 48.4 & Diluent \\
Mannitol & - & - & 14.7 & Diluent \\
Starcap 1500, pregelatinized corn starch & - & 57 & - & Diluent, disintegrant \\
Talc & 4.5 & - & - & Lubricant \\
Magnesium stearate & 0.5 & - & - & Lubricant \\
Aerosil & 0.5 & - & 0.9 & Glidant \\
Sodium lauryl sulfate & 1 & - & 1.1 & Surfactant \\
\hline Total & 100 & 100 & 100 & \\
\hline
\end{tabular}

\section{Flow properties}

Densities of bulk were examined as suggested by the British Pharmacopoeia's Technical Procedure "Apparent Volume" (British Pharmacopoeia, 2008) using an Erweka SVM volumeter. Deviating from the instructions, a $100 \mathrm{ml}$ graduated cylinder was used for better accuracy in reading volumes. The cylinder was filled with 25-35 g of OXC or excipients only (Sartorius 2482 balance, accuracy $\pm 0.1 \mathrm{mg}$ ). The initial volume was measured and poured densities calculated. After 1250 taps the corresponding volume was read to the nearest milliliter. $V_{1250}$ was used to calculate tapped density. The bulk and tapped densities were also determined for each formulation (drug + excipients).

From the bulk and tapped densities, Carr's index (CI) (Carr, 1965) was calculated for each formulation, using the following equation:

$$
C I=\frac{\rho \text { tapped }-\rho \text { bulk }}{\rho \text { tapped }} \times 100
$$

\section{Capsule preparation}

Micronized OXC and excipients were weighed, passed through a 16 mesh sieve and mixed for 5 minutes in a porcelain mortar and pestle. Magnesium stearate and/or aerosil were then added to each mixture, and the mixture was blended for 1 additional minute. The typical batch size was 100 capsules. All batches were prepared according to uniform procedures. All hard gelatin capsules were size 0 . The dose of OXC was $150 \mathrm{mg} /$ capsule. A manual filling machine was used.

\section{Physicochemical analyses of capsules}

Uniformity of weight and disintegration time were evaluated according to the methodologies described in the
British Pharmacopoeia (2008) and Brazilian Pharmacopoeia (1988), respectively.

\section{Assay and uniformity of content of capsules}

Quantitative analyses were carried out using the UV spectrophotometric method validated as described in the item "Validation of UV spectrophotometric method". Assay and content uniformity testing were performed for all formulations tested. Assay: twenty capsules were randomly selected and the quantity of powder equivalent to $100 \mathrm{mg}$ of OXC was dissolved in methanol, transferred to a $100 \mathrm{~mL}$ volumetric flask, and the volume completed with the same solvent. Content uniformity testing: ten capsules were randomly selected and individually assayed for OXC amount. The concentration of each batch was determined from the calibration curve previously obtained for a pure sample of OXC.

\section{Dissolution}

The amount of drug dissolved in 60 min was determined to evaluate the performance of the manipulated capsules and the influence of excipients on drug release. An experimental plan was developed to evaluate the influence of dissolution medium and stirring speed on the drug release behavior of each formulation. The dissolution conditions were: $900 \mathrm{ml}$ of water with 0.5 and $1.0 \% \mathrm{w} / \mathrm{v}$ of sodium lauryl sulphate (SLS) as dissolution medium, using a basket apparatus at a stirring speed of 75 and $100 \mathrm{rpm}$. The mediums were maintained at $37 \pm 0.5^{\circ} \mathrm{C}$. Sampling aliquots of $10 \mathrm{ml}$ were withdrawn at 30 and 60 minutes after placing the capsules in the dissolution medium. The drug release was evaluated by the UV spectrophotometric method at $305 \mathrm{~nm}$. The drug release percent was obtained by comparing the absorbance found after diluting the dissolution test aliquots with the absorbance of $100 \%$ 
theoretical dissolution concentration, while the dissolution profiles were obtained by plotting average percentage of drug release versus time.

The interference of SLS of the dissolution medium on the quantitative step of the dissolution profile was evaluated. The spectrum of the standard solutions of OXC $50.00 \mu \mathrm{g} / \mathrm{mL}$ (blank determination with SLS at the concentrations of $0.5 \%$ and $1.0 \%$ ) and the spectrum of the solutions containing 0.5 and $1.0 \%$ SLS (blank determination with water) were superimposed.

The linearity was evaluated by linear regression analysis, which was calculated by the least squares regression method. After the end of the test time, each sample aliquot was diluted to a suitable concentration to reach optimal absorption measurement of about 0.5 absorbance units. Data were analyzed using ANOVA and Tukey's tests.

\section{RESULTS AND DISCUSSION}

\section{Validation of UV spectrophotometric method}

The proposed UV method allows rapid and economical quantitation of $\mathrm{OXC}$ in capsules without any time-consuming sample preparation. Moreover, the spectrophotometric methods involve simple instrumentation compared with other instrument techniques. The stock solutions and working standards were made in methanol. The $\lambda$ max of the drug for analysis was determined by taking scans of the drug sample solutions in the entire UV region (200-400 nm). The wavelength $305 \mathrm{~nm}$ was then used for all measurements.

Linearity: the method demonstrated to be linear, with a correlation coefficient of the standard curve greater than 0.999. The linear regression equation was $\mathrm{y}=10.125 \mathrm{x}-0.0092$. Beer's law is obeyed over this concentration range.

Precision: in the intra-day precision analysis $(\mathrm{n}=6)$, the mean OXC content in the F1, F2 and F3 formulations were $98.98 \%$ (R.S.D. $=1.19 \%$ ), $95.98 \%$ (R.S.D. $=1.18 \%$ ) and $100.47 \%$ (R.S.D. $=1.03 \%$ ), respectively. The values found in the inter-day precision $(\mathrm{n}=12)$ were $98.89 \%$ (R.S.D. $=0.87 \%$ ), $95.75 \%$ (R.S.D. $=0.91 \%$ ) and $100.48 \%$ (R.S.D. $=1.25 \%$ ) for the formulations F1, F2 and F3, respectively. The R.S.D (\%) values obtained of less than $2.0 \%$, attested to the precision of the method.

Accuracy: the mean recovery $(\mathrm{n}=9)$ of OXC from the F1, F2 and F3 formulations were $100.38 \%$ (R.S.D. $=0.92 \%$ ), $100.04 \%$ (R.S.D. $=0.69 \%$ ) and $99.60 \%$ (R.S.D. $=0.79 \%$ ), respectively. These results indicate the accuracy of the proposed method for the determination of OXC.
Selectivity: placebo samples showed no interference in absorbance at $305 \mathrm{~nm}$. These results demonstrate the good selectivity of the method.

Robustness: the mean absorbances measured using two different spectrophotometer models (Hewlett Packard 8453 and Shimadzu 160A) were 0.504 and 0.499 , respectively. The experimental $t$ value (2.69) was lower than the table value (2.78), indicating there was no significant difference between the results from the two spectrophotometers.

Detection and quantification limits: the limit of detection of OXC achieved was $0.62 \mu \mathrm{g} / \mathrm{mL}$. The limit of quantification achieved with this method was $1.88 \mu \mathrm{g} / \mathrm{mL}$.

All the method validation parameters were well within the limits specified in the ICH Q2R1 guidelines (1996). A summary of results is shown in Table II.

\section{Development of capsule formulations}

\section{Differential scanning calorimetry (DSC)}

Interactions in the solid state among the active ingredient and excipients in pharmaceutical dosage forms can give rise to changes in the stability, solubility, dissolution rate and bioavailability of drugs. Therefore, it would be extremely useful in the development of new pharmaceutical formulations to have readily available knowledge about potential physical and chemical interactions between drugs and excipients. Differential scanning calorimetry (DSC) has shown to be a powerful tool in the first step of preformulation studies for investigating and predicting physicochemical incompatibility between a drug and pharmaceutical excipients (Giron, 2002). DSC compatibility studies were carried out by comparing the thermal curve of pure OXC with the curves obtained from pure OXC at $1: 1 \mathrm{w} / \mathrm{w}$ individual mixtures with each excipient under consideration.

The DSC curve of OXC was typical of a pure crystalline substance, showing a sharp endothermic peak at its melting point, with an onset temperature of $221.13^{\circ} \mathrm{C}$. No significant degradation was seen to occur before $240^{\circ} \mathrm{C}$. The melting temperature determined from the DSC curve was in accordance with that described in the literature, 219-221 ${ }^{\circ} \mathrm{C}$ (Carril et al., 2005).

OXC was found to be compatible with microcrystalline cellulose, starch and talc. Interaction between OXC and mannitol, monohydrate lactose, colloidal silica, magnesium stearate and sodium lauryl sulfate (SLS) was observed and the extent of interaction varied from only a shift in the OXC melting endotherm to total abolition of the peak (Table III). The absence of the melting endotherm of OXC from the mixture with SLS may be due to the dissolution of the drug in the melting of the SLS. 
TABLE II - Validation parameters for UV method of analysis of OXC

\begin{tabular}{|c|c|c|c|c|c|c|}
\hline \multirow{2}{*}{ Parameters } & & \multirow{2}{*}{$\begin{array}{l}\text { Acceptance } \\
\text { criteria }\end{array}$} & \multicolumn{4}{|c|}{ Results } \\
\hline & & & $\mathrm{OXC}$ & F1 & F2 & F3 \\
\hline \multicolumn{2}{|l|}{ Selectivity } & $\begin{array}{c}\text { Evaluated } \\
\text { the ability of } \\
\text { the proposed } \\
\text { method to } \\
\text { discriminate OXC } \\
\text { from placebo } \\
\text { formulations }\end{array}$ & - & $\begin{array}{c}\text { No interferences } \\
\text { from the } \\
\text { excipients }\end{array}$ & $\begin{array}{c}\text { No interferences } \\
\text { from the } \\
\text { excipients }\end{array}$ & $\begin{array}{c}\text { No interferences } \\
\text { from the } \\
\text { excipients }\end{array}$ \\
\hline \multicolumn{2}{|l|}{ Linearity } & $\mathrm{r}^{*}>0.999$ & 0.9997 & - & - & - \\
\hline \multirow{2}{*}{ Precision } & Intra-day & R.S.D. $* *<2 \%$ & $0.61 \%$ & $1.19 \%$ & $1.18 \%$ & $1.03 \%$ \\
\hline & Inter-day & R.S.D. $* *<2 \%$ & $0.67 \%$ & $0.87 \%$ & $0.91 \%$ & $1.25 \%$ \\
\hline \multirow{3}{*}{$\begin{array}{l}\text { Accuracy } \\
\text { (\% Recovery) }\end{array}$} & $80 \%$ & \multirow{3}{*}{$98-102 \%$} & \multirow{3}{*}{---} & $100.05 \%$ & $102.08 \%$ & $100.51 \%$ \\
\hline & $100 \%$ & & & $100.91 \%$ & $101.45 \%$ & $99.18 \%$ \\
\hline & $120 \%$ & & & $100.17 \%$ & $100.22 \%$ & $99.10 \%$ \\
\hline
\end{tabular}

*Correlation coefficient. **R.S.D. = Relative Standard Deviation

TABLE III - DSC data on drug and excipients

\begin{tabular}{lc}
\hline Sample & $\begin{array}{c}\text { Melting endotherm } \\
\text { onset }\left({ }^{(} \mathbf{C}\right)\end{array}$ \\
\hline OXC & 221.13 \\
OXC/ microcrystalline cellulose & 223.66 \\
OXC/starch & 218.81 \\
OXC/talc & 224.50 \\
OXC/sodium lauryl sulfate & - \\
OXC/mannitol & 208.63 \\
OXC/ colloidal silica & 206.11 \\
OXC/lactose & 199.40 \\
OXC/ magnesium stearate & 206.64 \\
\hline
\end{tabular}

Although some excipients were found to interact with $\mathrm{OXC}$, one cannot conclusively state this incompatibility will be encountered upon storage at room temperature. These results suggest that Formulation 2 was the best formulation among those studied (OXC is fully compatible with starch). Despite a possible incompatibility between $\mathrm{OXC}$ and some excipients of Formulations 1 and 3, these formulations were prepared in order to evaluate the effect of commonly used excipients on the extent and/or rate of drug release. It is noteworthy that these excipients are present in OXC tablets available in the pharmaceutical market.

\section{Flow properties}

Poured densities of the OXC and formulations (Ta- ble IV) ranged from $0.38 \mathrm{~g} / \mathrm{mL}(\mathrm{OXC})$ to $0.49 \mathrm{~g} / \mathrm{mL}$ (Formulation 3), and tapped densities from $0.49 \mathrm{~g} / \mathrm{mL}$ (OXC) to $0.64 \mathrm{~g} / \mathrm{mL}$ (Formulation 3 ). The values of the calculated CI (Table IV) ranged from 14.8 (Formulation 1) to 25.0 (Formulation 2). A CI below $15 \%$ is considered to be an indication of good flowability and thus Formulation $\mathbf{1}$ had excellent flowability. Formulations $\mathbf{2}$ and $\mathbf{3}$ had a CI above $15 \%$, which is regarded to represent the threshold between free flow $(<15 \%)$ and no flow $(>25 \%)$.

\section{Physicochemical analyses of capsules}

Initially, the physicochemical characteristics of the capsules were evaluated. The summary of the uniformity of weight and disintegration time is shown in Table V.

Mean weight, obtained from individual weights of 20 capsules, yielded information about the variations in weight in capsules from the same batch, constituting one of the parameters which could influence the active uniformity of content among different capsules. Determination of disintegration time evaluates the time necessary for the release of OXC from the capsule. The OXC must be released from the capsule as efficiently as possible to allow for its rapid dissolution. If a pharmaceutical agent is released from the capsule slowly it cannot have a rapid dissolution rate whereas if disintegration is rapid then rapid dissolution is possible.

All samples presented a weight variation of less than 7.5\% (British Pharmacopoeia, 2008) and a disintegration time (6-10 min) of less than 45 minutes (Brazilian Pharmacopoeia, 1988). Therefore, the results presented in Table V 
Table IV - Results of density measurements

\begin{tabular}{lcccccc}
\hline $\begin{array}{l}\text { Drug and } \\
\text { Formulations }\end{array}$ & $\begin{array}{c}\text { Sample mass } \\
(\mathbf{g})\end{array}$ & $\begin{array}{c}\text { Bulk volume } \\
(\mathbf{m L})\end{array}$ & $\begin{array}{c}\text { Tapped volume } \\
(\mathbf{m} \mathbf{L})\end{array}$ & $\begin{array}{c}\text { Bulk density } \\
(\mathbf{g} / \mathbf{m L})\end{array}$ & $\begin{array}{c}\text { Tapped density } \\
(\mathbf{g} / \mathbf{m} \mathbf{L})\end{array}$ & $\begin{array}{c}\text { Carr index } \\
(\mathbf{\%})\end{array}$ \\
\hline OXC & 25.35 & 66 & 51.5 & 0.3841 & 0.4922 & 22.0 \\
Formulation 1 & 29.01 & 61 & 52 & 0.4756 & 0.5579 & 14.8 \\
Formulation 2 & 29.85 & 64 & 48 & 0.4664 & 0.6219 & 25.0 \\
Formulation 3 & 30.00 & 61 & 47 & 0.4918 & 0.6383 & 22.9 \\
\hline
\end{tabular}

TABLE V - Physicochemical analyses of different formulations of OXC capsules

\begin{tabular}{lccc}
\hline Formulations & \multicolumn{2}{c}{ Mean weight $(\mathrm{N}=20)$} & Disintegration time $(\mathrm{min})(\mathrm{N}=6)$ \\
\cline { 2 - 3 } & \multicolumn{2}{c}{ Maximum deviation } & Minimum deviation \\
$\mathbf{1}$ & 4.93 & -5.51 & 10 \\
$\mathbf{2}$ & 5.95 & -2.87 & 10 \\
$\mathbf{3}$ & 5.67 & -3.99 & 6 \\
Limits & \multicolumn{2}{c}{ Max. 7.5\% } \\
\hline
\end{tabular}

showed that all evaluated formulations were in accordance with the official specifications.

\section{Assay and uniformity of content of capsules}

Subsequently the active substance was assayed and uniformity of content in the capsule samples was determined. The results of the drug assay and uniformity of content are shown in Table VI.

The drug assay is a test to compare the theoretical quantitative contents of active substances in dosage forms (declared value) with the real values, determined experimentally by their quantification using established and validated methods. There is no Pharmacopeia monograph establishing acceptance criteria for the assay of OXC. Therefore, we consider the commonly accepted limit of $92-108 \%$ of the label claim (specified limit for the carbamazepine). The analysis of the uniformity of content evaluates the drug dose variation among each unitary dosage form from the same batch.

Regarding the evaluation of the samples assay and its relation to the respective chemical reference substances, Formulations 1, 2 and $\mathbf{3}$ showed a drug content between $92 \%$ and $108 \%$ of the declared value for the active substance. In relation to the uniformity of content test, all samples met the general specification for capsules $(85 \%-115 \%$, $\mathrm{RSD} \leq 6.0 \%$ ) (Brazilian Pharmacopoeia, 1996).

\section{Dissolution}

The UV spectrophotometric method may be used for quantifying drug release in dissolution tests if the drug has a UV chromophore and no interference from formulation excipients or dissolution medium components are observed. Based on our results it is clear that there was no interference from dissolution medium in the absorption spectrum of OXC at the wavelength of $305 \mathrm{~nm}$, or the spectral profile from 200 to $400 \mathrm{~nm}$.

TABLE VI - Assay and uniformity of content of different formulations of OXC capsules

\begin{tabular}{lcccc}
\hline Formulations & $\begin{array}{c}\text { Assay } \pm \mathbf{C I} * \\
(\%)(\mathbf{N}=\mathbf{5})\end{array}$ & Higher & Uniformity of content (\%) (N= 10) \\
\cline { 2 - 5 } & $99.24 \pm 1.47$ & 104.20 & 93.82 & R.S.D.** (\%) \\
\hline $\mathbf{1}$ & $92.58 \pm 0.86$ & 98.12 & 89.16 & 2.65 \\
$\mathbf{2}$ & $99.50 \pm 0.63$ & 100.86 & 90.31 & 3.13 \\
$\mathbf{3}$ & $92-108 \%$ & & $85-115 \%$ & \\
Limits & & & RSD $^{* *}(\%): \leq 6.0$ & \\
& &
\end{tabular}

$* \mathrm{CI}=$ Confidence interval 0.95. ** R.S.D. $=$ Relative Standard Deviation 
The method demonstrated to be linear in the concentration ranges of $10-90 \mu \mathrm{g} / \mathrm{ml}($ SLS $0.5 \% \mathrm{w} / \mathrm{v}$ ) and $30-90 \mu \mathrm{g} / \mathrm{mL}$ (SLS $1.0 \% \mathrm{w} / \mathrm{v}$ ) and all correlation coefficients (r) were over 0.999 . The linear regression equation was $\mathrm{y}=0.0093 \mathrm{x}-0.0079$ for SLS $0.5 \% \mathrm{w} / \mathrm{v}$ and $\mathrm{y}=0.0091 \mathrm{x}-0.0046$ for SLS $1.0 \% \mathrm{w} / \mathrm{v}$. Beer's law is obeyed over this concentration range.

Based on FDA recommendations for water insoluble or sparingly water soluble drug products, use of a surfactant such as sodium lauryl sulfate is recommended where the surfactant should be used in the smallest possible amount (FDA, 1997). OXC is a sparingly water soluble drug and physiological variations in $\mathrm{pH}$ have no effect on its solubility (Flesch, 2004). Thus, the addition of LSS was necessary to enhance drug solubility. The experimental results suggest that SLS $0.5 \% \mathrm{w} / \mathrm{v}$ yielded a better dissolution medium condition. Therefore, the optimum dissolution conditions were determined as follows: $0.5 \%$ SLS as dissolution medium, in baskets at a stirring speed of $100 \mathrm{rpm}$ as apparatus and time of $30 \mathrm{~min}$, tolerance of $80 \%$, and determination accomplished by spectrophotometry at $305 \mathrm{~nm}$. The average percent release of OXC in 30 and 60 minutes, from the three formulations is shown in Table VII.

Table VII - Mean percent drug release from the three formulations in SLS 0.5\% (w/v) dissolution medium

\begin{tabular}{lcc}
\hline Formulations & \multicolumn{2}{c}{ \% Drug release (R.S.D.\%, $\mathrm{n}=6)$} \\
\cline { 2 - 3 } & \multicolumn{2}{c}{ SLS 0.5\% $100 \mathrm{rpm}$} \\
\hline $\mathbf{1}$ & $30 \mathrm{~min}$ & $60 \mathrm{~min}$ \\
$\mathbf{2}$ & $86.73(4.85)$ & $86.78(4.89)$ \\
$\mathbf{3}$ & $89.68(13.72)$ & $94.41(5.82)$ \\
\hline
\end{tabular}

Statistical methods based on the analysis of variance (ANOVA) and Tukey's test were used to compare the results of the dissolution test after 30 and 60 minutes. There was no significant difference between the data obtained from Formulations 1-3 after 30 minutes ( $p>0.05$ ). In contrast, there was a significant difference between the rates of dissolution of Formulations $\mathbf{1}$ and $\mathbf{2}$ after 60 minutes $(\mathrm{p}<0.05)$. Typical acceptance criteria for the amount of drug dissolved lie in the range of $85 \%$ dissolved after 30 minutes (FDA, 1997). All formulations presented more than $85 \%$ of OXC dissolved in 30 minutes.

$\mathrm{OXC}$ capsules are dosage forms for immediate release and therefore the tested formulations were adequate for this purpose.

\section{CONCLUSIONS}

In conclusion, the UV spectrophotometric method described in the present study has been shown to be accurate, sensitive, precise, rapid and easy to perform. In addition, the proposed method can be applied to the quality control analysis of OXC without interferences from the excipients normally used in capsule formulations. The method was successfully applied to analyze OXC in three developed formulations.

The dissolution test developed and validated for OXC capsules was considered satisfactory and can be used for quality control and pharmacotechnical development purposes. Rapid drug release was obtained from the three tested formulations.

Among the formulations tested, Formulation $\mathbf{2}$ was the best in terms of drug-excipient compatibility. In addition, Formulation 2 showed sufficient flowability to ensure uniform filling of capsules and a good dissolution profile.

\section{ACKNOWLEDGEMENTS}

The authors are grateful to the Brazilian Pharmacopoeia for the financial support and to the $\mathrm{CNPq}$ (Brazil).

\section{REFERENCES}

BRAZILIAN Pharmacopoeia. 4.ed. São Paulo: Atheneu, 1988. $268 \mathrm{p}$.

BRITISH Pharmacopoeia. London: The Stationary Office, 2008. $3500 \mathrm{p}$.

CARRIL, M.; SANMARTIN, R.; CHURRUCA, F.; TELLITU, I.; DOMÍNGUEZ, E. An advantageous route to oxcarbazepine (Trileptal) based on palladium-catalyzed arylations free of transmetallating agents. Org. Lett., v.7, p.4787-4789, 2005.

CARR, R. L. Evaluating flow properties of solids. Chem. Eng., v.72, p.163-168, 1965.

FOOD AND DRUG ADMINISTRATION. FDA. Guidance for industry: dissolution testing of immediate release solid oral dosage forms. Rockville: CMC, 1997. Available at: <http:// www.fda.gov/cder/Guidance/1713bp1.pdf $>$. Accessed on: 4 May 2008.

FLESCH, G. Overview of the Clinical Pharmacokinetics of Oxcarbazepine. Clin. Drug. Invest., v.24, p.185-203, 2004. 
GIRON, D. Applications of thermal analysis and coupled techniques in pharmaceutical industry. J. Therm. Anal. Cal., v.68, p.335-357, 2002.

ICH, International Conference on Harmonization. Validation of Analytical Procedures: Text and Methodology Q2(R1). 1996. Available at: http://www.ich.org/LOB/media/ MEDIA417.pdf. Accessed on: 10 jan. 2009.

KALIS, M. M.; HUFF, N. A. Oxcarbazepine, an antiepileptic agent. Clin. Therap., v.23, p.680-700, 2001.

PATHARE, D. B.; JADHAV, A. S.; SHINGARE, M. S. A validation stability indicating $\mathrm{LC}$ method for oxcarbazepine. J. Pharm. Biomed. Anal., v.43, p.1825-1830, 2007.
QI, M. L.; WANG, P.; WANG, L. J.; FU, R. N. LC method for the determination of oxcarbazepine in pharmaceutical preparations. J. Pharm. Biomed. Anal., v.31, p.57-62, 2003.

RAMAA, C. S.; CHOTHE, P. P.; NAIK, A. A.; KADAM, V. J. Spectrophotometric method for the estimation of oxcarbazepine in tablets. Indian J. Pharm. Sci., v.68, p.265266. 2006.

SHORVON, S. Oxcarbazepine: a review. Seizure, v.9, p.75-79, 2000.

Received for publication on $12^{\text {th }}$ May 2009 Accepted for publication on $27^{\text {th }}$ August 2009 